\title{
Introduction to the Special Issue on
}

\section{'University Governance and Creativity'}

\author{
GEORG KR ÜCKEN*, LARS ENGWALL** and \\ ERIK DE CORTE ${ }^{\dagger}$ \\ *University of Kassel, Germany. Email: kruecken@incher.uni-kassel.de \\ **Uppsala University, Sweden. Email: Lars.Engwall@fek.uu.se \\ ${ }^{\dagger}$ University of Leuven, Belgium. Email: erik.decorte@kuleuven.be
}

Higher education institutions in Europe have undergone remarkable transformations over the last two to three decades. Of particular importance here are the far-reaching changes in university governance structures. Changes related to higher education governance have also attracted the attention of researchers, as these changes have been broadly discussed and widely studied, quite often in an international comparative and interdisciplinary fashion. ${ }^{1}$ New Public Management reforms have challenged the traditional mode of university governance in Europe that was based on the interplay between strong state regulation and academic self-governance. In its place, a stronger sense of institutional accountability has now emerged. Various reasons explain the increased focus on institutional accountability. First, state regulations are changing as they are now increasingly exercised through target agreements with universities, in which the allocation of state resources follows concrete performance indicators. Detailed prescriptions of university behaviour by direct rules and regulations, on the other hand, play a weaker role in state governance. Second, intermediary organizations such as accreditation agencies, evaluation bodies, and university governance boards as well as the media, through ranking lists, increasingly shape the external governance of universities. These organizations do not substitute state governance however, but constitute an additional governance layer. Third, and along with these changes, the universities themselves are internally transforming into organizational actors, by becoming integrated, goal oriented and competitive entities wherein management and leadership play an ever-important role. ${ }^{2}$ Conceptualizing the university as an organizational actor is at odds with the traditional conception of European universities, both in academic writing and in universities' dayto-day practices. Up until the past few decades, universities were caught between the state and academic self-governance and, therefore, traditionally there was not much legitimate space for organizational management and leadership within universities. 
Both external and internal governance changes were spurred by a series of developments in national and European policymaking, which have strengthened the institutional and individual accountability in higher education while weakening professional self-control. Not surprisingly, these changes have generated a plethora of unintended consequences, and the criticism of New Public Management reforms has grown stronger over time, questioning the alleged de-bureaucratization and related positive spill-over effects on overall performance, university autonomy, and individual motivation. Numerous critical studies exist on accreditation and evaluation processes that came with the Bologna process, on university leadership and management, on new regulatory frameworks and the changing role of state therein, and on related changes within universities that come with such regulatory frameworks. ${ }^{3}$ These studies have generated a lot of insights, in particular by comparing different countries and universities. However, and this is striking, the existing studies barely address the effects of governance reforms on creativity, even though creativity is indispensable for conducting high-quality academic research, and high-quality academic teaching requires creativity as well. Studying creativity in the context of governance seems to be a veritable 'obstacle épistémologique', to make use of a concept introduced by the French philosopher of science, Gaston Bachelard. ${ }^{4}$ Not always entirely consciously, we make assumptions concerning a subject that do not allow us to fully explore that subject. Studying creativity in the context of governance is such an 'obstacle épistémologique' as we tend to associate creativity with the inner and unregulated properties of individuals.

At first glance, Robert K. Merton's posthumously published book, The Travels and Adventures of Serendipity, confirms this view with regard to science. ${ }^{5}$ On the basis of a lot of historical material, Merton, one of the founders of the scientific study of the science system, together with his co-author Elinor Barber, describes how the generation of scientific knowledge is characterized by non-linear processes, wherein surprise, deviation and luck are of paramount importance. Such processes can be handled only by exceptionally creative individuals. With the title of the book, the two authors refer to an ancient Persian fairy tale, 'The Three Princes of Serendip', to explain the processes of scientific discovery. During their travels, these three princes unintentionally deviate from their planned route, and as a result they have to deal actively and creatively with the unknown and the unexpected challenges encountered on their way. In this process, the three princes make important discoveries by accident. Merton and Barber use the travels of the three princes as a metaphor for scientific discoveries. For science, though, pure creativity does not suffice. It also needs, as Merton and Barber outline in their book, theoretical expectations and methodological skills in order to contextualize the unknown and the unexpected. In the words of Louis Pasteur: 'Le hasard ne favorise que les esprits préparés' ${ }^{6}$

What do these insights into the winding paths of science mean for the relationship between governance and creativity? Are they really two contradicting requirements for universities, who are expected to demonstrate both more accountability and more knowledge creation? Is this relationship a zero-sum game, in which more governance necessarily means less creativity and vice versa, or can we develop sensible syntheses 
between the two requirements? How should external rules and regulations be formulated in order to facilitate and not impede creativity? There are certainly no clear-cut answers to these questions, but they are eminent for the future of academia.

One approach to address these questions is to allow for what organizational researchers call 'slack' in universities. ${ }^{7}$ In most research, slack has a bad reputation as it implies wasting of resources within organizations. However, business firms increasingly make use of slack and deliberately do not use all of their resources efficiently by allowing their members to engage in activities that do not serve a clearcut purpose, and in this manner foster creativity and develop innovative solutions. However, for universities the opposite seems to be true. Increasing third-party competition, externally stimulated research networks, performance indicators and short-term incentive schemes are supposedly straightforward and lead towards a direction that hardly fosters creativity in research and teaching. Therefore, more slack would lessen the pressure on universities and their members by allowing for deviations and winding paths, being well aware of the fact that resources will not always be used efficiently and at times will even be wasted. Allowing for creativity by such indirect means implies a high degree of trust between the various governance actors that is not always given. The discussion of appropriate forms of university governance with regard to creativity expresses an erosion of trust. This situation requires serious answers from the academic field.

Against the above backdrop, the HERCulES group within Academia Europaea took the initiative for a conference on the topic 'University Governance: Impeding or Facilitating Creativity?'. It was realized in collaboration with the International Centre for Higher Education Research Kassel (INCHER-Kassel) at the University of Kassel, Germany and by means of generous support from, and in collaboration with, the German Volkswagen Foundation (VolkswagenStiftung). This special issue of European Review is based on papers presented at the conference that took place on 29 and 30 September 2016, at the Royal Palace of Herrenhausen, Hannover. It includes a broad variety of academic researchers dealing with issues of governance and creativity in universities as well as practitioners representing the field of higher education leadership.

The first contribution is the opening address by Wilhelm Krull, Secretary General of the Volkswagen Foundation, where he provides a background for the conference and sets the scene. He is followed by Ivar Bleiklie, who presents three different perspectives on the relation between university governance and creativity, i.e. with reference to the Medieval University, the Humboldt University and the present time managerial university. In relation to the latter, Michael Power discusses the recent requirements in the United Kingdom that universities should demonstrate the social and economic impact of their research. Performance management is also the topic of the contribution by Peter Scott, who elaborates on its relationship to new modes of learning, more open curricula and more distributed patterns of research.

In a second group of contributions, the paper by Francisco Michavila and Jorge Martinez analyses the relationship between autonomy and excellence in a group of countries. This in turn is closely related to the discussion of Jean-Claude Thoenig and Catherine Paradeise on higher education institutions as strategic actors and that of 
Jetta Frost and Fabian Hattke on ways to balance managerial and collegial governance and thereby create viable university commons. Similarly, Gerhard Casper in his contribution makes a plea for accountable leadership as well as flexibility on all levels in a university.

In a third group of contributions, Sandra Ohly provides a review of creativity research and discusses implications of this body of knowledge for universities, while Gili Drori presents governance models for academic creativity. They are followed by Jan De Groof, who argues that creativity among universities is likely to increase with a larger differentiation among them, and Lauritz B. Holm-Nielsen, who elaborates on the implications of universities moving from being local to global actors.

Together, the contributions in this Special Issue demonstrate that modern university governance may not always facilitate the creativity that is expected to be the hallmark of universities. In contrast, it may hamper creativity through too short-term perspectives. It therefore appears important for the future to find ways to handle the accountability of universities in a way that provides opportunities for them to contribute to a long-term creativity.

\section{References}

1. I. Bleiklie, J. Enders and B. Lepori (Eds) (2017) Managing Universities Policy and Organizational Change from a Western European Comparative Perspective (Palgrave Studies in Global Higher Education, Basingstoke: Palgrave Macmillan); and J. Frost, F. Hattke and M. Reihlen (Eds) (2016) Multi-level Governance in Universities: Strategy, Structure, Control (New York: Springer).

2. G. Krücken and F. Meier (2006) Turning the university into an organizational actor. In: G. Drori, J. Meyer and H. Hwang (Eds.), Globalization and Organization (Oxford: Oxford University Press), pp. 241-257.

3. See for example, R. Whitley, J. Gläser and L. Engwall (Eds) (2010) Reconfiguring Knowledge Production: Changing Authority Relationship in the Sciences and their Consequences for Intellectual Innovation (Oxford: Oxford University Press); and R. Whitley and J. Gläser (Eds) (2014) Organisational Transformation and Scientific Change: The Impact of Institutional Restructuring on Universities and Intellectual Innovation, Research in the Sociology of Organizations (Bingley: Emerald Group).

4. G. Bachelard (1938) La Formation de l'esprit scientifique: Contribution à une psychanalyse de la connaissance objective (Paris: J. Vrin).

5. R.K. Merton and E. Barber (2004) The Travels and Adventures of Serendipity: A Study in Sociological Semantics and the Sociology of Science (Princeton, NJ: Princeton University Press).

6. L. Pasteur and L.-P. Vallery-Radot (1939) Oeuvres de Pasteur. Tome 7, Mélanges scientifiques et littéraires (Paris: Masson \& Cie), p. 129.

7. R.M. Cyert and J.G. March (1963) A Behavioral Theory of the Firm (New Jersey: Prentice-Hall).

\section{About the Authors}

Georg Krücken is Director of the International Centre for Higher Education Research Kassel (INCHER-Kassel) and Professor of Sociology and Higher 
Education Research at the University of Kassel. After undergraduate and graduate studies in sociology, philosophy, and political sciences at Bielefeld University and the University of Bologna, Krücken received his $\mathrm{PhD}$ in sociology from Bielefeld University in 1996, where he worked as an associate professor until 2006. From 1999 to 2001 he was a visiting scholar at the Department of Sociology at Stanford University. He taught as a guest professor at the Institute for Science Studies, University of Vienna, and at the Centre de Sociologie des Organisations, Sciences Po, Paris. Before coming to Kassel he held the endowed Chair for Science Organization, Higher Education and Science Management at the University of Speyer. His research interests include science studies, organizational studies, the management of higher education, and neo-institutional theory.

Lars Engwall is professor emeritus of management at Uppsala University, Sweden. His research has been particularly directed toward the production and diffusion of management knowledge. Among his recent publications are From Books to MOOCs? (2016, ed. with Erik De Corte and Ulrich Teichler, Portland Press), Defining Management (2016 with Matthias Kipping and Behlül Üsdiken, Routledge) and Corporate Governance in Action (ed. 2018, Routledge). He is an elected member of a number of learned societies and has received honorary degrees from Åbo Akademi University and the Stockholm School of Economics.

Erik De Corte is Emeritus Professor (of Educational Psychology) in the Faculty of Psychology and Educational Sciences at the University of Leuven, Belgium, where he chaired, from August 1994 until July 1998, the Department of Educational Sciences. His major research interest is to contribute to the development of theories of learning from instruction and the design of powerful learning environments, focusing on learning, teaching, and assessment of thinking and problem solving. He was the first President (1985-1989) of the European Association for Research on Learning and Instruction (EARLI). In 2000 and 2003, respectively, he received doctorates honoris causa of the University of Johannesburg, and the University of the Free State, Bloemfontein, South Africa. During the academic year 2005-2006 he stayed as a Fellow at the Center for Advanced Study in Behavioral Sciences at Stanford, USA. (http://perswww.kuleuven.be/ u0004455) 